\title{
Short-day melatonin pattern advances puberty in seasonally breeding rhesus monkeys (Macaca mulatta)
}

\author{
M. E. Wilson and T. P. Gordon \\ Yerkes Regional Primate Research Center, Field Station, Emory University, 2409 Taylor Road, \\ Lawrenceville, GA 30243, USA
}

\begin{abstract}
Summary. Prepubertal, spring-born females (Group $\mathrm{H}$ : $\mathrm{N}=5$ ) living outdoors were given a daily injection of melatonin $(0.70 \mu \mathrm{g} / \mathrm{kg}, \mathrm{s.c}$.) late in the afternoon to produce a short-day melatonin pattern equivalent to a night of $\sim 14 \mathrm{~h}$. The dose of melatonin produced serum concentrations of melatonin which simply extended, within the $24 \mathrm{~h}$ day, the normal endogenous nighttime elevation $(80-100 \mathrm{pg} / \mathrm{ml})$. The study was started in March when the females were 23 months of age and continued through January. Parameters of sexual maturation for this group were compared to those of untreated, age-matched females (Group $\mathrm{C}: \mathrm{N}=5$ ) which also lived outdoors under changing environmental conditions. Melatonin treatment significantly advanced age at first perineal swelling $(23.9 \pm 0.5$ vs $30.5 \pm 0.2$ months $)$ and menarche $(26.2 \pm 0.9 \mathrm{vs}$ $31 \cdot 2 \pm 2 \cdot 4$ months). Since all of the females were spring-born, these events occurred earlier in the year in Group $\mathrm{H}$ females (swelling: April vs October; menarche: June $v s$ November). Furthermore, $4 / 5$ Group $\mathrm{H}$ females exhibited first ovulation in December at $31.8 \pm 0.3$ months. None of the Group $\mathrm{C}$ females ovulated during their 2 nd year, but all did so the next breeding season at $43.5 \pm 0.3$ months. All first ovulations in females had luteal-phase progesterone concentrations elevated for at least 12 days with peaks $>3.0 \mathrm{ng} / \mathrm{ml}$.
\end{abstract}

Body weights were similar between groups until the post-menarchial interval when weight gain was greater in the melatonin-treated females. A similar pattern of group differences also was observed for serum concentrations of growth hormone and somatomedin-C. In addition, prolactin concentrations were seasonally elevated during the summer months in both groups, but concentrations fell to nadir values by August in Group $\mathrm{H}$ females and remained elevated until October in Group $\mathrm{C}$ animals. These results suggest that, in adolescent females housed outdoors, exposure to a short-day melatonin pattern permits sexual maturation to be initiated at an earlier age, allowing first ovulation to occur in the months immediately after menarche. A long-day melatonin pattern, typically experienced by females at this developmental age, may actually delay the initiation of maturational events until the subsequent fall months.

Keywords: puberty; melatonin; rhesus monkey

\section{Introduction}

First ovulation for rhesus monkeys living outdoors is restricted to the fall or winter months (Wilson et al., 1984, 1986) regardless of season of birth (Wilson \& Gordon, 1989a). Development is prolonged in this species, typically spanning several years. For spring-born monkeys housed outdoors, concentrations of luteinizing hormone $(\mathrm{LH})$ in the absence of the ovaries begin to rise at $\sim 25$ months of age coincident with late spring (Wilson et al., 1986). Concentrations of LH in the presence of oestradiol do not rise until $\sim 29$ months of age the next fall. This delayed increase in 
basal LH concentrations in the presence of oestradiol has been attributed to enhanced oestradiol negative feedback inhibition of $\mathrm{LH}$, characteristic of the final stages of puberty (Rapisarda et al., 1983; Wilson et al., 1986). Menarche typically occurs at $\sim 30$ months of age while first ovulation occurs in a bimodal distribution with $20 \%$ of the females in this colony ovulating in early winter at $\sim 32$ months and the remaining in early fall at $\sim 42$ months (Wilson et al., 1984, 1986). Those females which enter the breeding season of their 2 nd year at a more advanced developmental age, based on age at increases in LH and menarche, are more likely to ovulate in that season (Wilson $e t$ al., 1986). The loss of non-gonadal restraint at $\sim 25$ months in these monkeys housed outdoors is similar to that of monkeys housed in a non-seasonal environment of $12 \mathrm{~h}$ light: $12 \mathrm{~h}$ dark (Terasawa et al., 1984a). Furthermore, under indoor housing conditions, intact females exhibit the increase in basal LH (Terasawa et al., 1984a) and menarche (Wilson et al., 1988) at an earlier age, with a greater percentage having first ovulation during their 2 nd year, than animals housed in a seasonal environment (Wilson et al., 1988). These results suggest that the annual exposure to the warm, long days of spring and summer may delay sexual maturation, while the removal of these cues allows development to proceed unhindered by external events.

For rhesus monkeys, it is not known what environmental cue regulates either the seasonal restriction of first ovulation or the seasonal distribution of ovulation exhibited by adult females (Walker et al., 1984). In other seasonally breeding mammals, photoperiod and its subsequent generation of a particular pattern of pineal melatonin secretion is the predominant cue regulating reproductive function (Bronson, 1988). A particular pattern of photoperiodic changes is critical for the appropriate timing of first ovulation in lambs (Foster, 1983), an effect dependent upon the generation of the appropriate $24 \mathrm{~h}$ melatonin rhythm (Yellon \& Foster, 1986). The species-specific photoperiodic requirements for the normal onset of pubertal events is also observed for ferrets (Ryan \& Robinson, 1987), hamsters (Sisk \& Turek, 1983) and deer mice (Garcia \& Whitsett, 1983). Based on the importance of photoperiod and the presumed changes in the daily melatonin rhythm, the seasonal pattern of reproductive development in female rhesus monkeys may be due to photoperiodic changes mediated by a daily melatonin rhythm. The present study was therefore undertaken to determine whether the premature exposure of immature female rhesus monkeys to a short day melatonin pattern would advance the timing of maturation with respect to the occurrence of menarche and first ovulation. In addition to these reproductive events, serum concentrations of prolactin, growth hormone $(\mathrm{GH})$ and somatomedin- $\mathrm{C}$ were monitored to assess how these changed with alterations in the timing of maturation.

\section{Materials and Methods}

Animals. The female rhesus monkeys were allocated to $\operatorname{Group} \mathrm{H}(\mathrm{N}=5$, melatonin treatment $)$ and Group $\mathrm{C}(\mathrm{N}=5$, control). All females were born in late winter or early spring (Group H: 19 April $\pm \mathbf{4 \cdot 0}$ days; Group C: 24 March \pm 11.4 days) and had lived outdoors from birth. Reproductive data for the Group $\mathrm{C}$ animals have been presented elsewhere (Wilson et al., 1988). The subjects were members of social groups containing several adult males and females housed in outdoor enclosures $(30 \times 30 \mathrm{~m})$ with attached indoor quarters as described previously (Walker et al., 1982). The indoor quarters provided heat during the inclement winter months and were only illuminated during daylight hours. Animals were provided with commercial monkey food (Wayne Products, Chicago, IL, USA) ad libitum and were given fresh fruit once daily. Water was available at all times.

Procedures. Melatonin treatment was initiated on 3 March when females were 22.4 $( \pm 0.1)$ months of age. Melatonin (Sigma Chemical Corp., St Louis, MO, USA) was suspended in sesame oil and injected s.c., at a concentration of $0.7 \mu \mathrm{g} / \mathrm{kg}$. This concentration was empirically derived as it elevated serum concentrations of melatonin within $2 \mathrm{~h}$ of injection to concentrations typically observed during the night in age-matched females. As illustrated in Fig. 1, serum increases in melatonin occurred after sunset in Group $\mathrm{C}$ females during both July and December whereas increases occurred within $2 \mathrm{~h}$ after melatonin treatment in Group $\mathrm{H}$ females. Complete data on nycthemeral patterns of melatonin during development in rhesus monkeys are presented elsewhere (Wilson \& Gordon, 1989b). The time of the afternoon injection therefore varied, depending upon the prevailing photoperiod so that serum melatonin concentrations would be elevated in the Group $\mathrm{H}$ females for about $14 \mathrm{~h}$ each day throughout the study (Fig. 2). Since exogenously administered melatonin does not influence endogenous secretion (Lang et al., 1983), the injections preceded sunset by no more than $4 \mathrm{~h}$, effectively producing a short-day rhythm of melatonin of $\sim 10 \mathrm{~h}$ of low serum concentrations and $\sim 14 \mathrm{~h}$ of elevated serum concentrations. 


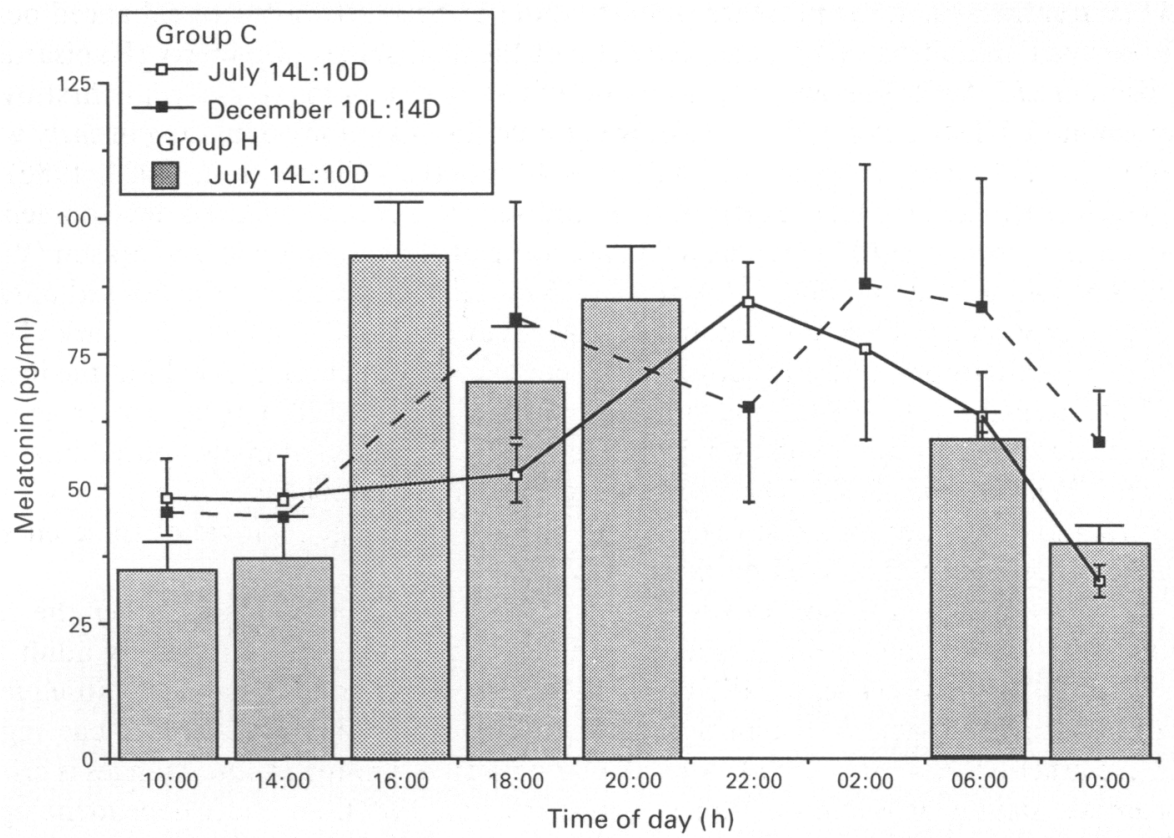

Fig. 1. Patterns of serum melatonin concentrations (mean \pm s.e.m.) over $24 \mathrm{~h}$ in 5 Group $\mathrm{H}$ females during July and in 5 Group C females during July (sunset at 19:51 h and sunrise at 05:52 h) and during December (sunset at 17:51 h and sunrise at 07:51 h). The number of hours of daylight to darkness for each sampling is expressed as L:D. Melatonin was administered to Group $\mathrm{H}$ females at 14:00 h.

Melatonin treatment was initiated before the expected age of the initial increases in basal LH in outdoor-housed control females (Wilson et al., 1986). Furthermore, by starting treatment at this time (March) females were not exposed to any days in which endogenous melatonin was elevated for less than $12 \mathrm{~h}$. Treatment with melatonin was continued through $\sim 33$ months of age or first ovulation, whichever occurred first. This age was chosen as it represents the earliest age at which normal, spring-born females ovulate within the seasonally circumscribed breeding season (Wilson et al., 1986). A positive effect of the melatonin treatment would be an earlier occurrence of first ovulation (i.e. $<30$ months of age) or more females ovulating at the early age ( $>20 \%$ by 33 months of age). Either outcome would indicate that exposure to a short-day melatonin pattern from 22 months of age allowed maturation to proceed by eliminating inhibitory long-day effects.

Analyses. Blood samples were collected twice weekly from the capture-accustomed subjects as previously described (Walker et al., 1982). Menstrual bleeding was detected by daily visual inspection. Perineal swelling, characterisitic of young sexually mature female rhesus monkeys, was rated twice weekly as described previously (Wilson et al., 1986). Immature animals have a rating of 0 (no colour and no swelling) while the initial readings, characteristic of puberty onset, typically are $1(0.5$ colour and 0.5 swelling) and maximum readings would be 6 . Body weights were obtained monthly following an $18-\mathrm{h}$ overnight fast. Ovulation was inferred from sustained elevations in serum progesterone concentrations $(>1.0 \mathrm{ng} / \mathrm{ml}$; Foster, 1977).

Serum concentrations of oestradiol were determined from samples collected twice weekly by radioimmunoassay (RIA) using a modification of a commercially available kit (Diagnostic Products Corp., Los Angeles, CA, USA). Rather than using human serum as the assay diluent, serum from gonadectomized rhesus monkeys was further treated with charcoal to remove residual steroids (Fraser et al., 1983) and was used as the diluent in the assay. The assay sensitivity $(80 \%$ bound) was $7-10 \mathrm{pg} / \mathrm{ml}$, with between- and within-assay coefficients of variation $(\mathrm{CV})$ of 9.4 and $2 \cdot 8 \%$, respectively. Serum progesterone was quantified in twice weekly samples by RIA using a commercially available kit (Diagnostic Products Corp.). Assay sensitivity was $0.3 \mathrm{ng} / \mathrm{ml}$ with between- and within-assay CVs of 8.6 and $2.9 \%$, respectively. Serum prolactin (Wilson et al., 1985), GH and somatomedin-C (Wilson, 1986), and melatonin (Reppert et al., 1979) concentrations were determined by double-antibody RIA as described previously. Serum concentrations of prolactin, $\mathrm{GH}$, and somatomedin-C were determined in twice monthly samples. CVs for these assays were all $<9 \%$.

The results are given as mean \pm s.e.m. Comparisons between Group $\mathrm{H}$ and Group $\mathrm{C}$ over time were made with analysis of variance for repeated measures or, when appropriate, $t$ tests for independent samples. Comparisons 
between groups at specific ages were made with Scheffé post-hoc tests. All statistical tests having a $P$ value of $<0.05$ were considered significant.

\section{Results}

\section{Reproductive patterns}

Females given a short-day melatonin pattern exhibited sexual maturation at a significantly earlier age. Age at the initial perineal swelling (Fig. 2) was significantly earlier in Group $\mathrm{H}$ $\left(23.9 \pm 0.5\right.$ months) than in Group C females $\left(30.5 \pm 0.2\right.$ months; $\left.t_{8}=12.01\right)$ and consequently significantly earlier in the year (18 April \pm 12 days $v s 17$ October \pm 7 days; $t_{8}=3 \cdot 88$ ). In addition, age at menarche was significantly advanced in Group $H$ females $(26.2 \pm 0.9$ vs $31.2 \pm 2.4$ months; $t_{8}=10 \cdot 36$ ) and this also occurred significantly earlier in the year (24 June \pm 11 days vs 11 November \pm 8 days; $t_{8}=8.96$ ). Age at first ovulation was also significantly advanced in $4 / 5$ of Group $\mathrm{H}$ females, occurring at $31 \cdot 8( \pm 0 \cdot 3)$ months on an average date of 11 December ( \pm 3 days). The remaining Group $\mathrm{H}$ female did not ovulate by 33 months of age when treatment was discontinued, although age at swelling (23.2 months) and menarche (26.3 months) was indistinguishable from the other animals in Group $\mathrm{H}$. In contrast, none of the Group $\mathrm{C}$ females exhibited first ovulation during their 2 nd year, but all exhibited a normal first ovulation the subsequent breeding season at $43 \cdot 5( \pm 0 \cdot 3)$ months on an average date of 3 November ( \pm 7 days). First ovulation for the Group $\mathrm{H}$ females was associated with normal luteal-phase progesterone levels with peak values (based on twice weekly samples) between 4 and $9 \mathrm{ng} / \mathrm{ml}$ with concentrations remaining above follicular-phase values $(<0.3 \mathrm{ng} / \mathrm{ml})$ for $13.0 \pm 0.8$ days.

\section{Endocrine changes}

Serum oestradiol concentrations varied significantly between groups throughout development (Fig. 2; $F_{19,152}=5.91$ ). Although serum oestradiol concentrations were significantly increased in Group $\mathrm{H}$ females from 27 through 28 months, a period which followed the average age at menarche for this group, significant differences between groups were due to higher oestradiol concentrations in Group $\mathrm{H}$ females after 30.5 months, reflecting the increased serum concentrations associated with the occurrence of first ovulation for $4 / 5$ of these females.

Serum concentrations of $\mathrm{GH}$ also varied during development (Fig. $3 \mathrm{a} ; \mathrm{F}_{9,72}=3.41$ ). In a pattern similar to that of oestradiol, GH concentrations were significantly increased in Group $\mathrm{H}$ females from 27 through 30 months of age. Concentrations of somatomedin-C followed a similar time course (Fig. $3 b ; F_{9,72}=7 \cdot 88$ ). Unlike $\mathrm{GH}$ though, concentrations of somatomedin-C remained elevated significantly in Group $\mathrm{H}$ females from 27 months of age until the end of data collection.

Serum concentrations of prolactin (Fig. 3c) were similar between Group $\mathrm{H}$ and Group C females until 28 months of age (August) and then concentrations were significantly reduced in Group $\mathrm{H}$ females until 30 months of age when values had fallen significantly in Group $\mathrm{C}$ females $\left(F_{9,72}=3 \cdot 12\right)$. The normal seasonal decline in serum prolactin concentrations therefore occurred significantly earlier in animals treated with melatonin.

\section{Body weight changes}

Body weights at the start of the study were similar between Group C $(3.02 \pm 0.11 \mathrm{~kg})$ and Group H $\left(3.28 \pm 0.07 \mathrm{~kg} ; t_{8}=1.75\right)$ females. Overall weight gains were significantly greater for Group H $(1.52 \pm 0.05 \mathrm{~kg})$ than Group C $\left(1.20 \pm 0.10 \mathrm{~kg} ; t_{\mathbf{8}}=2.60\right)$ females. These differences were due to significant weight gains made after menarche for Group $\mathrm{H}$ animals as weight gains before age at menarche for Group $\mathrm{H}$ animals $(0.48 \pm 0.04 \mathrm{~kg})$ were not different from those observed for Group C females $\left(0.46 \pm 0.05 \mathrm{~kg} ; t_{8}=0.29\right)$. 


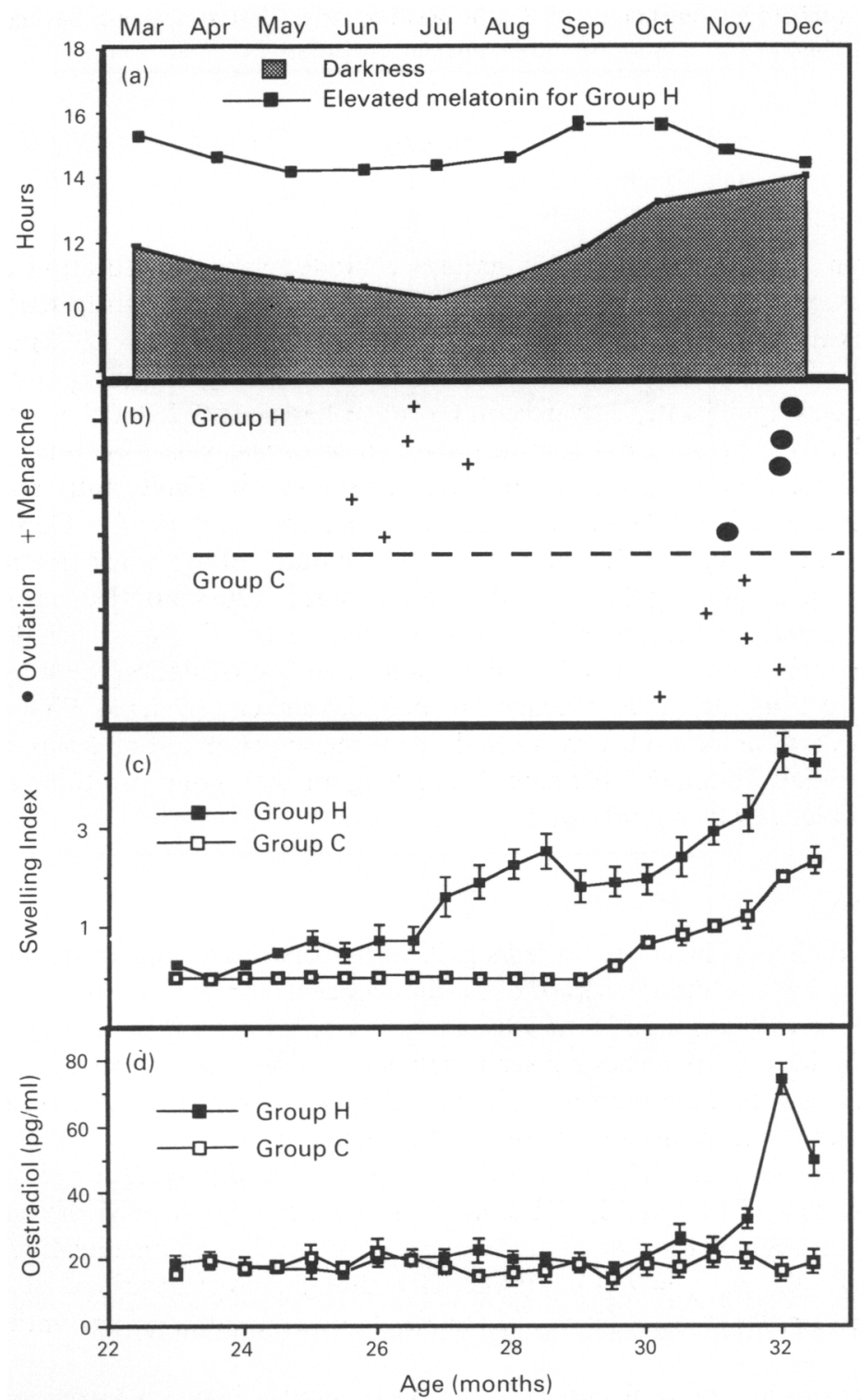

Fig. 2. Results for monkeys in Groups $\mathrm{H}$ and $\mathrm{C}$ for (a) changes in the expected duration of elevated serum melatonin for Group $\mathrm{H}$ females relative to the number of hours of darkness throughout the study period; (b) the occurrence of menarche, and when appropriate, first ovulation for individual Group $\mathrm{H}$ and $\mathrm{C}$ females; and mean \pm s.e.m. changes in (c) perineal swelling and coloration and (d) serum oestradiol concentrations throughout the study.

\section{Discussion}

Administration of a short-day melatonin pattern to premenarchial rhesus monkeys housed under natural long days resulted in a significantly earlier occurrence of menarche and, in $80 \%$ of females, first ovulation. Females also exhibited perineal swelling, characterisitic of young sexually mature females (Hartman, 1932), significantly earlier than control animals. Although none of the Group C females ovulated during their 2nd year, previous studies (Wilson et al., 1984, 1986) indicate that 


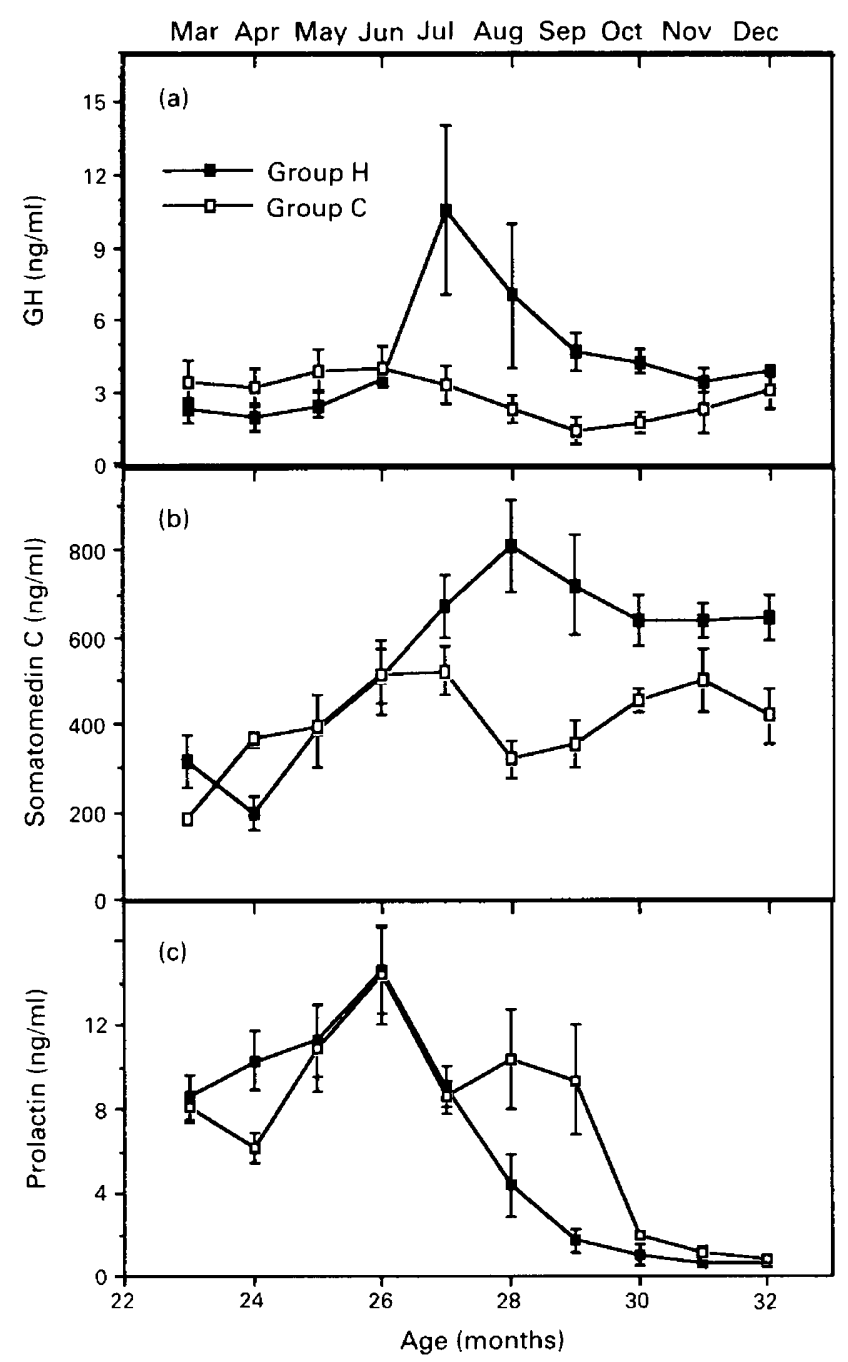

Fig. 3. Serum concentrations (mean \pm s.e.m.) of (a) GH, (b) somotomedin-C, and (c) prolactin for Group $\mathrm{H}$ and Group $\mathrm{C}$ females throughout the course of the study.

$\sim 20 \%$ of colony females ovulate at that age. The observation that $80 \%$ of the melatonin-treated females ovulated at an early age therefore suggests that the treatment effectively accelerated the timing of maturation in this seasonally breeding species.

The results of the present study support the hypothesis that photoperiod-induced changes in nycthemeral melatonin secretion regulate the seasonal occurrence of first ovulation in rhesus monkeys. Similar to the melatonin treatment used in the present study, removal of seasonal photoperiod and temperature cues by housing females in a $12 \mathrm{~h}$ of light:12 $\mathrm{h}$ of dark environment also advances puberty (Wilson et al., 1988): age at menarche is earlier and the majority ovulate between 31 and 33 months of age. The hypothesis must be entertained that exposure of premenarchial females ( $\sim 23$ months of age) to a long-day pattern of melatonin delays the onset of puberty. If these cues are absent, puberty is initiated in the months immediately after the expected age at which non-gonadal restraint of LH secretion diminishes (Terasawa et al., 1983; Wilson et al., 1986). Indeed, the interval from menarche to first ovulation in the Group $\mathrm{H}$ females was $\sim 6$ months, 
compared to $\sim 12$ months for Group $\mathrm{C}$ monkeys. Those spring-born females that do ovulate during their 2 nd year have $\sim 3$ months between menarche and first ovulation (Wilson et al., 1986). The data suggest that, independent of any seasonal influence, a specific interval of at least 3-6 months must elapse between the initial signs of puberty and first ovulation, reflecting the continued maturation of the neuroendocrine system which is characterized by a decrease in the effectiveness of oestradiol to inhibit LH secretion (Rapisarda et al., 1983; Wilson et al., 1986; Winter et al., 1987). If females do not ovulate within the perimenarchial fall months, first ovuation is delayed until the next autumn due to enhanced oestradiol negative feedback inhibition of LH during the intervening spring and summer months (Wilson et al., 1986). Although an hypothesis that seasonal changes can modify the timing of puberty seems probable based on the present data, no affirmative data are available ascribing a role of photoperiod in the regulation of seasonal occurrence of ovulations in adult female rhesus monkeys (Wehrenberg \& Dyrenfurth, 1983; Keverne, 1987).

The parameter of the daily melatonin rhythm manipulated in the present study was nocturnal duration. Although manipulation of this variable does affect the timing of puberty in lambs (Yellon \& Foster, 1986), other aspects of the nycthermeral rhythm, such as peak amplitude or timing of the change in melatonin, may also be important (Arendt et al., 1981). However, recent data indicate that the duration of the nocturnal increase and not its timing during a $24 \mathrm{~h}$ period mediates the photoperiod effects on reproduction in sheep (Wayne et al., 1988). Furthermore, cross-sectional data from children (Waldhauser et al.. 1988) and longitudinal assessment of female rhesus monkeys (Wilson \& Gordon, 1989b) indicate that nocturnal concentrations of melatonin decrease throughout puberty, suggesting that this change may be a cue for puberty onset independent of photoperiod effects. If this is the case, then a dual role for melatonin may be implicated for puberty onset in seasonally breeding rhesus monkeys: (1) a decrease in nocturnal melatonin concentrations provides the neuroendocrine signal for the initiation of puberty and (2) once this occurs, the particular pattern of the melatonin rhythm (i.e. long day/short day) sets the timing for the completion of puberty.

Although the occurrence of an early first ovulation was increased in the melatonin-treated animals, the age and timing within the breeding season at which this occurred was not different from that observed for the $20 \%$ of the spring-born females that ovulate during their 2 nd year (Wilson et al., 1984, 1986). This suggests that: (1) the earliest age possible for rhesus females to ovulate may be $\sim 31$ months or (2) the fact that these females had lived in a seasonal environment before the start of treatment may have determined the 'window' within which first ovulation could occur. Although episodic administration of LH-releasing hormone (Wildt et al., 1980) can initiate ovulatory cycles at a prepubertal age, reports from a variety of laboratories indicate that spontaneous first ovulations do not occur before 31 months (Krey et al., 1981; Norman \& Spies, 1981; Resko et al., 1982; Terasawa et al., 1984a). Indeed, hypothalamic disconnection (Norman \& Spies, 1981) and posterior hypothalamic lesions (Terasawa et al., 1984b) advance first ovulations relative to control females, but these still do not occur before 31 months of age. Thus, although the timing of maturation can be advanced, the earliest possible age at first ovulation may be fixed. The ovulations produced by the short-day melatonin pattern in the present study should not be considered precocious. Indeed, the hypothesis generated from the present results suggests that the inhibitory long days of spring and summer delay maturation and if these are removed by exposure to a shortday melatonin pattern or removal of seasonal cues maturation will proceed (Wilson et al., 1988).

As an alternative to this explanation, Group $\mathrm{H}$ females lived continuously for 22 months in a seasonal environment before the start of treatment. Although treatment advanced maturation, it may not have advanced the clock controlling the occurrence of first ovulation. Since development extends over several years in rhesus monkeys, the early exposure to an annual photoperiodic cycle may play a role in the ultimate timing of first ovulation. This is in contrast to that of other mammals which have first ovulation before one annual cycle has elapsed, like the lamb for example, which has first ovulation within 35 weeks of birth (Foster, 1983). In the present study, Group H and Group $\mathrm{C}$ females exhibited a seasonal rhythm in prolactin concentrations with high summer values 
and low fall values, characteristic of adolescent rhesus monkeys living outdoors (Wilson et al., 1985). However, as the transition to fall began concentrations of prolactin fell significantly earlier in Group $\mathbf{H}$ females. Although melatonin treatment to ewes results in a fall in serum prolactin concentrations within 3 weeks (Kennaway et al., 1982), treatment of ram (Kennaway \& Gilmore, 1985) and ewe (Kennaway et al., 1986) lambs does not lower prolactin concentrations. Nevertheless, the significance of the earlier seasonal decrease in serum prolactin observed in the Group $\mathrm{H}$ females is not known. Reports of laboratory housed female rhesus monkeys suggest that decreases in serum prolactin are associated with greater developmental increases in LH (Schultz \& Terasawa, 1985). The question remains then whether initiation of short-day melatonin treatment 12 months earlier at 11 months of age might have reset the clock regulating the occurrence of first ovulation. Directly altering the photoperiod cycles would determine how the light:dark cycle regulates the timing of maturation and the occurrence of first ovulation independent of an internal clock.

Assessment of the endocrine and weight changes associated with advanced maturation in melatonin-treated females provides important information regarding how physical maturation may be influenced by sexual development. Significant increases in serum oestradiol for Group $\mathbf{H}$ were not observed until 27 months of age, after the occurrence of menarche as found in other studies (Terasawa et al., 1984a; Wilson et al., 1986). Correspondingly, the pattern of GH and somatomedin-C secretion paralleled that of oestradiol. These results support the hypothesis that maturational increases in GH secretion may, in part, be due to increases in ovarian oestradiol secretion (Copelant et al., 1984; Mansfield et al., 1988), and that these two hormones act synergistically to enhance somatomedin-C secretion (Wilson, 1986). Nevertheless, greatest increases in GH occurred for Group $\mathrm{H}$ females well before significant maturational increases in oestradiol had occurred ( 30 months), suggesting that maturational increases in $\mathrm{GH}$ are not due solely to increases in oestradiol. Increases in body weight were indistinguishable between groups until 28 months, $2-4$ months after the initial signs of puberty. These data suggest that the initiation of puberty, characterized by menarche but regulated by the initiation of LH secretion (Ryan, 1986) is not associated with significant increases in body weight as proposed previously (see Frisch, 1984). Rather, the present results support previous reports (Terasawa et al., 1984b; Wilson et al., 1986) that significant body weight gains may be a consequence rather than a prerequisite of pubertal development.

We thank K. Chikazawa, S. Glasco, E. Knobloch and E. Series for technical assistance; L. Wright for editorial assistance; the National Hormone and Pituitary Program for reagents for the GH and somatomedin-C assays; and Dr. G. Niswender, Colorado State University, for the antiserum to melatonin. This work was supported by NIH HD16305 and, in part, by RR00165. The Yerkes Primate Center is fully accredited by the American Association for the Accreditation of Laboratory Animal Care.

\section{References}

Arendt, J., Symons, A.M. \& Laud, C. (1981) Pineal function in the sheep: evidence for a possible mechanism mediating seasonal reproductive activity. Experientia 33, 584-591.

Bronson, F.H. (1988) Seasonal regulation of reproduction in mammals. In The Physiology of Reproduction, vol. 2, pp. 1831-1871. Eds E. Knobil, J. D. Neill, L. L. Ewing, G. S. Greenwald, C. L. Market \& D. W. Pfaff. Raven Press, New York.

Copeland, K.L., Johnson, D.M., Kuehl, T.J. \& Castracane, V.D. (1984) Estrogen stimulated growth hormones and somatomedin-C in castrate and infant female baboons. J. clin. Endocr. Metab. 58, 698-704.

Foster, D.L. (1977) Luteinizing hormone and progesterone secretion during sexual maturation in the rhesus monkey: short luteal phases during the initial men- strual cycles. Biol. Reprod. 17, 584-590.

Foster, D.L. (1983) Photoperiod and sexual maturation of the female lamb: early exposure to short day perturbs estradiol feedback inhibition of luteinizing hormone secretion and produces abnormal ovarian cycles. Endocrinology 112, 11-17.

Fraser, S., Cowen, P., Franklin, M., Franey, C. \& Arendt, J. (1983) Direct radioimmunoassay for melatonin in plasma. Clin. Chem. 29, 396-397.

Frisch, R.E. (1984) Body fat, puberty and fertility. Biol. Rev. 59, 161-190.

Garcia, I.M.P.S. \& Whitsett, J.M. (1983) Influence of photoperiod and social environment on sexual maturation in female deer mice. J. comp. Psychol. 97, 127-134.

Hartman, C.G. (1932) Studies in the reproduction of the 
monkey Macaca (Pithecus) rhesus, with special reference to menstruation and pregnancy. Contrib. Embryol. Carn, Instn 134, 3-161.

Kennaway, D.J. \& Gilmore, T.A. (1985) Effects of melatonin implants in ram lambs. J. Reprod. Fert. 73, 85-91.

Kennaway, D.J., Gilmore, T.A. \& Seamark, R.F. (1982) Effect of melatonin feeding on serum prolactin and gonadotropin levels and the onset of seasonal estrous cyclicity in sheep. Endocrinology 110, 1766-1772.

Kennaway, D.J., Peek, J.C., Gilmore, T.A. \& Royles, P. (1986) Pituitary response to LHRH, LH pulsatility and plasma melatonin and prolactin in ewe lambs treated with melatonin implants to delay puberty. $J$. Reprod. Fert. 78, 137-148.

Keverne, E.B. (1987) Processing environmental stimuli and primate reproduction. $J$. Zool. Lond. 213, 395408.

Krey, L.C., Hess, D.L., Butler, W.R., Espinosa-Campos, J., Lu, K.H., Piva, F., Plant, T.M. \& Knobil, E. (1981) Medial basal hypothalamic disconnection and the onset of puberty in the female rhesus monkey. Endocrinology 108, 1944-1951.

Lang, U., Aubert, M.L., Conne, B.S., Bradtke, J.C. \& Sizonenko, P.C. (1983) Influence of exogenous melatonin on melatonin secretion and the neuroendocrine reproductive axis of intact male rats during sexual maturation. Endocrinology 112, 1578-1584.

Mansfield, M.J., Rudlin, C.R., Crigler, J.F., Karol, K.A., Crawford. J.D., Boepple, P.A. \& Crowley, W.F. (1988) Changes in growth and serum growth hormone and plasma somatomedin- $C$ levels during suppression of gonadal sex steroid secretion in girls with central precocious puberty. J. clin. Endocr. Metab. 66, 3-11.

Norman, R.L. \& Spies, H.G. (1981) Brain lesion in infant female rhesus monkeys: effects on menarche and first ovulation and on diurnal rhythms of prolactin and cortisol. Endocrinology 108, 1734-1729.

Rapisarda, J.J., Bergman, K.S., Steiner, R.A. \& Foster D.L. (1983) Response to estradiol inhibition of tonic luteinizing hormone secretion decreases during the final stage of puberty in the rhesus monkey. Endocrinology 112, 1172-1179.

Reppert, S.M., Perlow, M.J., Tamarkin, L. \& Klein, D.C. (1979) A diurnal melatonin rhythm in primate cerebrospinal fluid. Endocrinology. 104, 295-301.

Resko, J.A., Goy, R.W., Robinson, J.A. \& Norman, R.L. (1982) The pubescent rhesus monkey: some characteristics of the menstrual cycle. Biol. Reprod. 27, 354-361.

Ryan, K.D. (1986) Maturation of the hypothalamicpituitary axis regulating gonadotropic secretion in the primate. Sem. Reprod. Endocrinol. 4, 23-231.

Ryan, K.D. \& Robinson, S.L. (1987) A study of spontaneous sexual maturation of the female ferret. Biol. Reprod. 36, 333-339.

Schultz, N.J. \& Terasawa, E. (1985) Seasonal changes in prolactin in peri-pubertal female rhesus monkeys. Biol. Reprod. 32, (Suppl. 1), 177, Abstr.

Sisk, C.L. \& Turek, F.W. (1983) Developmental time course of pubertal and photoperiodic changes in testosterone negative feedback on gonadotropin secretion in the golden hamster. Endocrinology 112, 1208-1216.
Terasawa, E., Nass, T.E., Yeoman, R.R., Loose, M.D. \& Schultz, N.J. (1983) Hypothalamic control of puberty in the female rhesus macaque. In Neuroendocrine Aspects of Reproduction, pp. 149-182. Ed. R. L. Norman. Academic Press, New York.

Terasawa, E., Bridson, W.E., Nass, T.E., Noonan, J.J. \& Dierschke, D.J. (1984a) Developmental changes in luteinizing hormone secretion pattern in peripubertal female rhesus monkeys: comparisons between gonadally intact and ovariectomized animals. Endocrinology 115, 2233-2240.

Terasawa, E., Noonan, J.J., Nass, T.E. \& Loose, M.D. (1984b) Posterior hypothalamic lesions advance the onset of puberty in the female rhesus monkey. Endocrinology 115, 2241-2250.

Waldhauser, F., Weiszenbacher, G., Tatzer, E., Gisinger, B., Waldhauser M., Schemper, M. \& Frisch, H. (1988) Alterations in nocturnal serum melatonin levels in humans with growth and aging. J. clin. Endocr. Metab. 66, 648-652.

Walker, M.L., Gordon, T.P. \& Wilson, M.E. (1982) Reproductive performance in capture acclimated female rhesus monkeys (Macaca mulatta). J. med. Primatol. 11, 291-302.

Walker, M.L., Wilson, M.E. \& Gordon, T.P. (1984) Endocrine control of the seasonal occurrence of ovulation in rhesus monkeys housed outdoors. Endocrinology 114, 1074-1081.

Wayne, N.L., Malpaux, B. \& Karsch, F.J. (1988) How does melatonin code for day length in the ewe: duration of melatonin release or coincidence of melatonin with a light-entrained sensitive period? Biol. Reprod. 39, 66-75.

Wehrenberg, W.B. \& Dyrenfurth, J. (1983) Photoperiod and ovulatory menstrual cycles in female macaque monkeys. J. Reprod. Fert. 68, 119-122.

Wildt, L., Marshall, G. \& Knobil, E. (1980) Experimental induction of puberty in the infantile female rhesus monkey. Science, N.Y. 207, 1373-1375.

Wilson, M.E. (1986) Gonadal steroids influence serum somatomedin-C concentrations in prepubertal female rhesus monkeys. Endocrinology 119, 666-671.

Wilson, M.E. \& Gordon, T.P. (1989a) Season determines timing of first ovulation in rhesus monkeys (Macaca mulatta) housed outdoors. J. Reprod. Fert. 85, 583-591.

Wilson, M.E. \& Gordon, T.P. (1989b) Nocturnal changes in serm melatonin during female puberty in rhesus monkeys: a longitudinal study. J. Endocr. (in press)

Wilson, M.E., Gordon, T.P., Blank, M.S. \& Collins, D.C. (1984) Timing of sexual maturity in female rhesus monkeys (Macaca mulatta) housed outdoors. $J$. Reprod. Fert. 70, 625-633.

Wilson, M.E., Walker, M.L., Schwartz, S.M. \& Gordon, T.P. (1985) Gonadal status influences developmental patterns of serum prolactin in female rhesus monkeys housed outdoors. Endocrinology 116, 640-645.

Wilson, M.E., Gordon, T.P. \& Collins, D.C. (1986) Ontogeny of luteinizing hormone secretion and first ovulation in seasonal breeding rhesus monkeys. Endocrinology 118, 293-301.

Wilson, M.E., Gordon, T.P., Rudman, C.G. \& Tanner, J.M. (1988) Effects of a natural versus artificial environment on the tempo of maturation in female rhesus monkeys. Endocrinology 123, 2653-2660.

Downloaded from Bioscientifica.com at 04/26/2023 01:42:03PM 
Winter, J.S.D., Ellsworth, L., Fuller, G., Hobson, W.C Reyes, F.L. \& Faiman, C. (1987) The role of gonadal steroids in feedback regulation of gonadotropin secretion at different stages of primate development. Acta endocr., Copenh. 114, 257-263.
Yellon, S.M. \& Foster, D.L. (1986) Melatonin rhythms time photoperiod-induced puberty in the female lamb. Endocrinology 119, 44-49.

Received 21 July 1988 